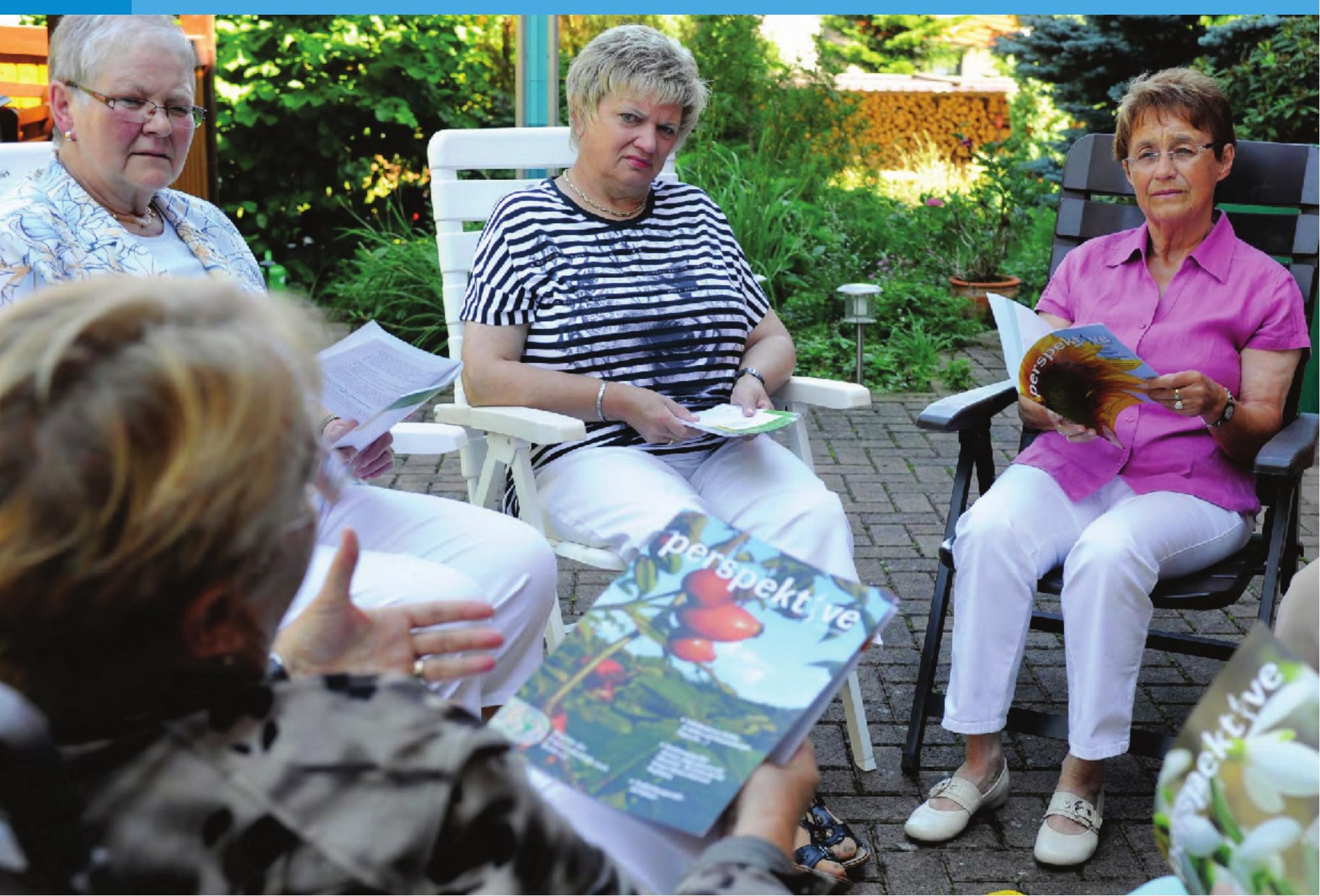

Interview mit Hilde Schulte • Ehrenvorsitzende der Frauenselbsthilfe nach Krebs

\title{
Medizin darf nicht verstummen
}

\section{In der Selbsthilfearbeit hat das Gespräch noch einen hohen Stellenwert}

Früher teils als exotisch belächelt, hat sich die Selbsthilfe mittlerweile fest in der medizinischen Landschaft etabliert und ist aus ihr kaum mehr wegzudenken. Hilde Schulte, Ehrenvorsitzende der Frauenselbsthilfe nach Krebs, begann nach der eigenen Brustkrebserkrankung, sich in der Krebsselbsthilfe zu engagieren und kann mittlerweile auf eine jahrelange Erfahrung zurückblicken. 